\title{
THE ANALYSIS OF NOUN DERIVED FROM ADJECTIVE IN BARACK OBAMA'S SPEECH AND THE TEACHING OF GRAMMAR
}

\author{
${ }^{1}$ Terra Tampangella \& ${ }^{2}$ Titi Rokhayati \\ ${ }^{1}$ English Student, FKIP, Purworejo Muhammadiyah University, Indonesia \\ ${ }^{2}$ English Lecturer, FKIP, Purworejo Muhammadiyah University, Indonesia \\ Corresponding Author Email: trokhayati@umpwr.ac.id
}

\begin{tabular}{|c|c|}
\hline Article Info & Abstract \\
\hline $\begin{array}{l}\text { Article History } \\
\text { Received: January } 2021 \\
\text { Revised: March } 2021 \\
\text { Published: April } 2021\end{array}$ & $\begin{array}{l}\text { The study was mixed-method research. This research deals with a derived noun } \\
\text { from an adjective found in Barack Obama's speech. The research objectives are } \\
\text { to find the position of the derived noun from adjectives in the sentence pattern } \\
\text { found in Barack Obama's speech and to describe the application of noun derived }\end{array}$ \\
\hline $\begin{array}{l}\text { Keywords } \\
\text { Writing instructions; } \\
\text { ELT learning; } \\
\text { Communicative learning; }\end{array}$ & $\begin{array}{l}\text { from adjective to teach grammar. In collecting the data, the researchers read the } \\
\text { script. Then, the data are identified derived nouns from adjectives. The data are } \\
\text { analyzed in relation to the theory of derived nouns from the adjective. The types } \\
\text { of data are quantitative and qualitative. The result shows that there are three } \\
\text { positions of the noun derived from adjectives based on sentence pattern. They are } \\
30 \text { SVO (Subject + Verb + Object) (50\%), } 18 \text { SVA ( Subject + Verb + Adverb) } \\
\text { (30\%), } 12 \text { SVC ( Subject + Verb + Complement) (20\%). The teacher could apply } \\
\text { the derived noun in pre-teaching by describing Barrack Obama's characters } \\
\text { while teaching by explaining part of speech and post-teaching by strengthening } \\
\text { the use of noun derived from adjective as one of part of speech in which it becomes } \\
\text { the most important piece in a sentence. }\end{array}$ \\
\hline
\end{tabular}

How to cite: Tampangella, T., \& Rokhayati, T. (2021). The analysis of noun derived from adjective in barack obama's speech and the teaching of grammar, JOLLT Journal of Languages and Language Teaching, 9(2), 250256, DOI: https://doi.org/10.33394/jollt.v\%vi\%i.3488

\section{INTRODUCTION}

Communication is a process by which a message or information is exchanged from a sender to a receiver. It involves a systematic and continuous process of telling, listening, and understanding. Communication is a part of human life. It happens every time and everywhere. With communication, people can understand what people want to convey to others and also respond to them. Everybody has their way to our communications with others. The basic component of communication is language. There are so many kinds of languages in the world, including English. English is the number one language in the world. Many countries already use the English language for daily communication. English is a language that everyone must master because English is an international language. There are more than 70 countries that use the English language to be the first language.

Besides, there are some components such as grammar and vocabulary. One of the most important language items that should be taught to students is grammar. Grammar is an important part of learning English. When students can not understand well about grammar, learners will be confused to arrange the sentence in English. Grammar explains the forms and structure of words and how they are arranged in sentences.

In other words, grammar provides the rules for the common use of both spoken and written language so we can more easily understand each other. There are hundreds of grammar rules but the basics refer to sentence structure and parts of speech. The part of speech explains the ways words can be used in various contexts. Altenberg (2010) states that part of speech is the name given to a group of words that has something in common, such as where they can go 
in a sentence. Connected with making a sentence, they are eight parts of speech. They are noun, verb, pronoun, adjective, adverb, determiner, preposition, and conjunction. A noun is a part of speech that names a person, place, thing, idea, action, or quality. Many students do not understand the importance of a noun. Nouns are important because they refer to places, objects, and people and the more sophisticated abstract concepts.

Nouns give important messages in a sentence. There are several derivations from nouns. Noun derivation is a process with which it can easily expand the vocabulary. There are kinds of noun derivation, a noun derived from a verb, a noun derived from an adjective. Noun derives from a verb is a word spelled with a final consonant preceded by either two vowels or additional consonants or with a vowel preceded by a consonant. There is an example of a noun derived from a verb ( moral+-ize). Adjectives, in terms of semantic sense, refer "to express property concepts" (Pustet, 2006, p. Adjectives, in terms of semantic sense, refer "to express property concepts" (Pustet, 2006, p.

One of the most important in nouns is a noun derived from an adjective. They have special forms to show numbers, and in some cases, to show gender. They cannot show tense or voice. They are usually the subjects or the objects of a verb or are used with a preposition. They only 'Case From' that they have in the possessive. Nouns have no degrees of comparison. In a text, there are written text and spoken text. One of the spoken texts is speech. Speech is the production of sounds that make up words and sentences. These sound units are combined so that they make up words and sentences.

One of the important people in which his speech can influence other people is Barack Obama. He is the number one person in the United States of American as a president from 2007 until 2017. He has good skills and good speech in front of the public. He has a good speech to attract his audience. The importance of Barack Obama's Speech to the people is to understand the importance of nouns derived from an adjective. People find nouns derived from adjectives from Barack Obama's speech. For that reason, the researchers want to analyze Barack Obama's speech, especially in the use of nouns derived from an adjective. Hopefully, this study gives benefits the teaching of grammar because of its importance.

\section{RESEARCH METHOD}

\section{Research Design}

This research can be categorized as mix-method research in which represents research that involves collecting, analyzing, and interpreting quantitative and qualitative data in a single study or in a series of studies that investigate the same underlying phenomenon (Leech $\mathrm{N}$, Onwuegbuzie A, 2008). However, the quantitative method is also needed to process some data that can only be represented in numbers and tables. Nonetheless, this research does not use a too complicated formula to present the finding. The quantitative method is only used to calculate the percentage of the noun derived from the adjective. Meanwhile, the qualitative approach described and gave details analysis of information in the form of sentences. It represents an interesting and various way of doing research.

The data of this research are nouns derived from adjectives found in Barack Obama's Speech. The researcher analyzed the noun derived from adjectives based on the suffix. The instrument of the research is the researchers themselves. According to Sugiyono (2011) in qualitative research, there's no other choice than to use man as the main instrument of the research. Sugiyono (2011) states that the researcher as a human instrument determines to focus on the research, select the subject of the research, collect data resources, analyze data, interpret data, and make a conclusion as the result of the research.

The researchers collect the data of nouns derived from an adjective that was applied to the words in Barack Obama's speech. Then, the researcher identifies nouns derived from adjectives found in Barack Obama's speech. After that, the researchers classify the types of the 
noun derived from adjectives in the table Then, describe the structures. At first, this step was carried out by showing the structure of nouns derived from the adjective. The Object of the are five speeches script of Barack Obama. This study randomly selected five speeches that contain 14515 words from American Rhetoric.com. Refer to the former website. The main contents consist of 5 themes.

\section{Instruments}

The main instrument used in this research is the researchers themselves. The documentation is chosen as another instrument because the researchers use the script of Barack Obama's speech. First, researchers find Barack Obama's scripts, then try to find all the nouns, then select the adjectives derived from the noun.

\section{Data Analysis}

The researchers collect the data of nouns derived from an adjective that was applied to the words in Barack Obama's speech. Then, the researchers identify nouns derived from adjectives found in Barack Obama's speech. Next, the researcher classifies the types of the noun derived from the adjective in the table. Then, describing the types of the noun derived from an adjective. At first, this step was carried out by showing the formation of the noun derived from the adjective. Second, describe the noun head and the suffix. The last the researchers determine the steps of the teaching of the noun derived from the adjective in English class.

\section{RESEARCH FINDINGS AND DISCUSSION \\ Research Findings}

The noun derived from Adjectives

There are many kinds of noun, the focus of the research was analyzed the noun derived from adjective found in Barack Obama Speeches.

Table 1

The noun derived from adjective found in the Barack Obama Speech

\begin{tabular}{llll}
\hline No & Noun derived from adjective & Urgent & Adjective \\
\hline 1 & Urgency & Busy & cy \\
\hline 2 & Business & Hopeful & ness \\
\hline 3 & Hopefulness & Stable & ness \\
\hline 4 & Stability & Flexible & ity \\
\hline 5 & Flexibility & Responsible & ity \\
\hline 6 & Responsibility & Generous & able \\
\hline 7 & Generosity & Possible & ity \\
\hline 8 & Possibility & Wilder & ity \\
\hline 9 & Wilderness & Senior & ness \\
\hline 10 & Seniority & Aware & Ity \\
\hline 11 & Awareness & Serious & ness \\
\hline 12 & Seriousness & Happy & ness \\
\hline 13 & Happiness & Righteous & ness \\
\hline 14 & Righteousness & Loyal & ness \\
\hline 16 & Loyalty & Presumptuous & ity \\
\hline 17 & Presumptuousness & Small & Ness \\
\hline 18 & Smallness & Different & Ness \\
\hline 19 & Differences & Equal & Ence \\
\hline 20 & Equality & Independent & Ity \\
\hline 21 & Independence & Secure & Ence \\
\hline 22 & Security & Great & Ity \\
\hline 23 & Greatness & Dark & Ness \\
\hline 24 & Darkness & Different & Ness \\
\hline 25 & Differences & Absent & Ence \\
\hline 26 & Absence & Ence \\
\hline & & &
\end{tabular}


Based on the table above, the researcher concludes thatnouns derived from adjectives were found in Barack Obama's speech. The noun derived from adjectives is noun with affix ness, a noun with affix -ity, a noun with affix -ence.

The position of the noun derived from an adjective on the sentence pattern

Tabel 2

Type of Noun Derived from Adjective based on the sentence pattern

\begin{tabular}{ccccc}
\hline No. & & Sentence Pattern & Number & Percentage \\
\hline 1. & SVO & & 30 & $50 \%$ \\
\hline 2. & SVA & & 18 & $30 \%$ \\
\hline 3. & SVC & & 12 & $20 \%$ \\
\hline & & Total & 60 & $100 \%$ \\
\hline
\end{tabular}

Notes:

SVO : Subject-Verb-Object

SVA : Subject-Verb-Adverb

SVC : Subject-Verb-Complement

Based on the calculation above, SVO is the most dominant type of sentence pattern where the nouns derived from adjectives have the Object position. The percentage of SVO is dominant because it has $50 \%$. And then, it was followed by SVA in a percentage of $30 \%$. The last is SVC in the percentage of $20 \%$

\section{Discussion}

The researchers analyzed nouns derived from adjectives found in Barack Obama's speech one by one. Firstly, the researchers identify the noun derived from adjectives found in Barack Obama's speech. Secondly, the researchers describe the construction of nouns derived from adjectives found in Barack Obama's speech. Finally, the researchers explained the changes in nouns derived from adjectives. In this part, the researcher explains the analysis of nouns derived from adjectives found in Barack Obama's speech. The detailed explanations are as follow:

The position of the noun derived from the adjective in the sentence SVO ( Subject+Verb+Object)

The sentence "You feel the same urgency" consists of the subject, verb, and Object. The subject in the sentence is you. The verb in the sentence is feel. And the Object is the same urgency (urgent $+\mathbf{c y}$ ). Based on the sentence above, the researcher concludes that the pattern of the sentence is SVO. The second sentence is "Now business not only has the ability to move jobs wherever there's a factory". In this sentence above, there is a subject, a verb, and an object and three adverbs, one before the subject to explain the whole sentence now, second before the verb, not only, third after the Object to explain the Object in the form of clause wherever there's a factory. The Object is the ability (able + ity) to move jobs and the verb is has.

The sentence seems difference structures such as if you feel the same hopefulness. In this sentence, there is a subject, a verb, and an object. The subject in the sentence is you. The verb in the sentence is feel and the Object is the same hopefulness (hopeful + ness). If is an adverb of condition since it is a dependent clause. That is what is produced our unrivaled political stability. In the sentence, there is a subject, a verb, and an object. The subject in the sentence is what. The verb in the sentence is produced in the form of the verb phrase. And the Object is our unrivaled political stability (stable + ity). Based on the explanation above, the researcher concludes that SVO is used in the sentence.

The other example is so you all had the flexibility. In the sentence above, there is subject, a verb, and an object. The subject in the sentence is you all. The verb in the sentence had, the 
Object is the flexibility (flexible + ity). So in the beginning of the sentence is adverb of purpose. Republicans will have to recognize our collective and responsibilities In this sentence, there is a subject, a verb, and an object. The subject in the sentence is Republicans. The verb in the sentence will have to recognize our collective in the form of verb Phrase, and the Object is our collective and responsibilities (responsible + ity). The sentence "a people met the generosity" seems different structure. The sentence consists of a subject, a verb, and an object. The subject in the sentence is a people. The verb in the sentence is met. And the Object is the generosity (generous + ity). The sentence "will have to accept responsibility for instilling" consists of verbs, and an object. It has no subject. The verb in the sentence will have to accept. And the Object is responsibility (responsible + ity) for instilling. Based on the explanation above, the $\mathrm{VO}$ is the sentence pattern with the omitting of the subject. He takes the reins of an organization that's wandering in the wilderness. In this sentence, there is a subject, a verb, and an object. The subject in the sentence is He. The verb in the sentence is takes. And the Object is the reins of an organization that's wandering in the wilderness (wilder + ness). Based on the explanation above, the researcher concludes that SVO is the sentence pattern.

\section{SVA (Subject, Verb, Adverb)}

The sentence "Now, keep in mind that I am ranked 99th in seniority" consists of subjects, verbs, and objects. The subject in the sentence is Now, keep in mind-the verb in the sentence that. And the Object is that I am ranked 99th in seniority (senior + ity). Based on the explanation above, the researcher concludes that SVO is used in the sentence. And we heard $\underline{\text { a }}$ King's call to let "justice roll down like waters, and righteousness like a mighty stream. In the sentence above, there is a subject, a verb, and an adverb. The subject in the sentence is we. The verb in the sentence heard, the complement is a King's call, and the adverb is to let "justice roll down like waters, and righteousness (righteous + ness) like a mighty stream in the form of the adverbial clause. The clause "which shows excellent situational awareness" consists of a subject, a verb, and an adverb. The subject in the sentence is which. The verb in the sentence is shows. And the adverb is excellent situational awareness.

Let us resolve that all nations including my own will act with the same seriousness. In this sentence, there is a subject, a verb, and three adverbs. The subject in the sentence is all nations including my own in the form of the noun phrase. The verb in the sentence is will act, and the adverbs are let us resolve (adverbial clause), that (sub-ordinate conjunction), with the same seriousness (serious + ness) (in the form of prepositional phrase). Based on the explanation above, the reseacher concludes that SVA is used in the sentence. if we committed ourselves to invest in these possibilities. In this sentence, there is a subject, a verb, an object and two adverbs. The subject in the sentence is we. The verb in the sentence is committed the Object is ourselves. There are two adverbs in this sentence, they are if (as an adverb of condition) and to investing in these possibilities (possible + ity) (as an adverb of purpose). Based on the explanation above, the sentence pattern is SVOA, and the noun derived from adjective has the position as an adverb.

\section{SVC ( Subject+Verb+Complement)}

The sentence "these are Life, Liberty and the pursuit of Happiness consists of a subject, a verb, and complements. The subject in the sentence is these. The verb in the sentence is are. And the complement is the life, liberty and the pursuit of Happiness (happy + ness). Based on the explanation above, the researcher concludes that SVC used in the sentence. Has my loyalty. In this sentence, there is no subject, a verb, and a compliment. The verb in the sentence is has. And the complement is my loyalty (loyal + ity). The sentence has no subject. The sentence is VC pattern. The sentence "I recognize that there is a certain presumptuousness consists of 2 subjects, 2 verbs, and a compliment. The subject in the sentence is $I$, and there that there is. The verbs in the sentence are recognized and is. And the complement is the a certain 
presumptuousness (presumptuous + ness). Based on the explanation above, the sentence is complex sentence with double $\mathrm{S} V$.

The sentence "what's stopped us is the failure of leadership the smallness of our politics" consists of a subject, a verb, and a compliment. The subject in the sentence is What's stopped $u s$. The verb in the sentence is $i s$. And the complement is the failure of leadership, the smallness (small + ness) of our politics. Based on the explanation above, the sentence consist of SVC, the complement is in the form of the noun phrase. There have been differences between America and Europe. In this sentence, there is a subject, a verb, and a complement. The subject in the sentence is There. The verb in the sentence is have been. And the complement is differences (different + ence) between America and Europe. Based on the explanation above, the sentence pattern is SVC.

Based on the discussion above, it is found that the most dominant sentence pattern is SVO where the Object is a noun derived from an adjective for the reason that what Barrack Obama intend in his speech is he wants his people to do what he said about some policies related to his country and also about game. He mostly used the SVO pattern for the reason that word order refers to the way words are arranged in a sentence. The standard word order in English is SVO. To determine the proper sequence of words, in this case, the students should understand what $\mathrm{SVO}$ is.

Teachers may use Barack Obama's speech to teach grammar to help English students learn more about nouns derived from an adjective.The aim of teaching grammar using nouns derived from adjective is to help English students understand the noun derived from the adjective. Barack Obama's speech can be used as the material to help English students to have experience. It can help them to improve their grammar mastery in the teaching-learning process. In pre-teaching teacher can give the story about the popularity of Barrack Obama, the American President who is charismatic, a good listener, attractive and impressive. He can make the students interested in Barrack Obama's figure then explain Barrack Obama's speech, which is always smart and interesting. In the whilst teaching, the teacher shows a piece of speech script of Barrack Obama, then relates it to Part of Speech. One of them is a noun. The noun can be classified into kinds and some derivation, from a verb or from the adjective. Giving the examples is the next step, then discusses with the piece of speech script and asks them to find nouns, especially nouns derived from adjectives. The post teaching can be done by analyzing the noun derived from adjective and their position in the sentence pattern.

\section{CONCLUSIONS}

There are 26 nouns derived from adjective found in the Barack Obama Speeches, which have suffix -cy, -ness, -ity, and -ence. There are three types of sentence pattern where nouns derived from adjectives have the positions of $\mathrm{O}, \mathrm{A}$, and $\mathrm{C}$ in Barack Obama's speech script. Nouns as Objects in the sentence were the most frequently used in the speeches. Nouns as adverbs were the second, and Nouns as Complement were the third. The phenomenon of this study corresponds with several theoretical concepts of the noun derived from the adjective. Based on its types, they are $30 \mathrm{O}(50 \%), 18 \mathrm{~A}(30 \%), 12 \mathrm{C}(20 \%)$. The researchers apply noun derived from the adjective in teaching grammar inserted in the topic of part of speech and making use of Barrack Obama's speech as the materials by breaking out the sentences and finding out the noun especially nouns derived from adjective at the eleventh grade of senior high school.

In teaching nouns, teachers should begin to explain the elements that can construct the noun (Pradnyan I., et.al., 2014). It can illustrate to the students in constructing nouns, especially nouns derived from adjectives. It is very important as the students often find difficulties in constructing nouns derived from an adjective. 


\section{REFERENCES}

Alternberg, Evelyn P. \& Robert M. V. (2010). English grammar understanding the basic. New York: Cambridge University Press.

Setyani, D.P., Hartono, R., Priyatmojo, A.S. (2017). Students' problems in making derivational words. Journal of English Language Teaching. ELT FORUM 6 (1) (2017)

Dykes, B. (2007). Grammar for everyone. Australia. BPA Print Group.

Haspelmath, Martin and Andrea D.S. (2010). Understanding morphology. London: Hodder Education.

Jitpranee, J. A. (2017). Study of Adjective Types and Functions in Popular Science Articles. International Journal of Linguistics. ISSN 1948-5425. 2017, Vol. 9, No. 2

Kollin, M. \& Robert, F. (2009). Understanding english grammar $9^{\text {th }}$ edition. Pearson Education, Inc.

Kothari, C. R. (2004). Research Methodology, Methods, and Techniques (Second Revised Edition). New Delhi : New

Kuzar, R. (2012). Sentence patterns in English and Hebrew. John Benjamins B.V.

Leech N, Onwuegbuzie A, (2008) A typology of mixed methods research designs,

Maddox, M. \& Daniel, S. (2009). Basic english grammar. Daily Writing Tips.

Payne, J., Huddleston, R., \& Pullum, G. K. (2010). The distribution and category status of adjectives and adverbs. Word structure, 3(1), 31-81. Retrieved from http://www.lel.ed.ac.uk/ gpullum/E1750124510000486.pdf.

Pradnyan I., et.al. (2014). Developing students' mastery on noun phrase in sentence construction of the eleventh graders through constituent test. e-Journal of English Language Teaching Society (ELTS) Vol. 2 No. 42014 - ISSN 2331-1841

Pustet, R. (2006). Adjectives. Encyclopedia Elsevier.

O'Hair, D. 2009. A pocket guide to public speaking. United States of America.

O'hair, D., et al. (2010). A pocket guide to public speaking. New York: Bedford/ st. Martin's.

Quirk, R., Greenbaum, S., Leech, G., \& Svartvik, J. (1985). A comprehensive grammar of the english language. New York: Longman

Sugiyono. (2011). Metode penelitian kuantitatif, kualitatif, dan R\&D. Bandung: Alfabeta. 